\title{
Antibacterial activity of lupeol from the bark of Dehaasia cuneate (Lauraceae)
}

\author{
Andi Rifki Rosandya,b*, Sumail Sidik Ode Ishak ${ }^{\mathrm{b}, \mathrm{c}}$, Noor Aziiraa Sabri ${ }^{\mathrm{a}}$, Wan Yaacob Wan Ahmad ${ }^{\mathrm{a}}$, Laode \\ Muhammad Ramadhan Al Muqarrabund
}

aSchool of Chemical Sciences and Food Technology, Faculty of Science and Technology Universiti Kebangsaan Malaysia, 43650 UKM Bangi, Selangor, Malaysia

bUniversity Center of Excellence for Nutraceuticals, Biosciences and Biotechnology Research Center, Bandung Institute of Technology, Bandung, Indonesia 40132

'School of Pharmacy, Bandung Institute of Technology, Bandung, Indonesia 40132

dSchool of Science UNSW Canberra at the Australian Defence Force Academy (ADFA), Canberra BC 2610, Australia

\section{ABSTRACT}

Dehaasia cuneata, locally known in Malaysia as 'gajus hutan or pekan', belongs to family Lauraceae. From its bark, A triterpenoid, lupeol was isolated and characterized. The chemical structure of the isolated compound was determined using spectroscopic methods, such as UVvis, FT-IR, 1D \& 2D-NMR, and ESIMS spectrometer. The isolated compound was tested against Gram-negative and positive bacteria using agar disc diffusion technique. The results showed that lupeol had a moderate inhibition zone value of $10.0 \pm 0.00 \mathrm{~mm}$ against Gram-negative Serratia marcescens ATCC 14756 whereas low inhibition which is $7.0 \pm 0.00 \mathrm{~mm}$ against Escherichia coli ATCC 25922, Vibrio fluvialis ATCC 33809, Bacillus subtilis ATCC 6633, and Methicillin-resistant Staphylococcus aureus (MRSA) ATCC 43300.

\author{
Article history: \\ Received 21 Jan 2021 \\ Revised 19 Feb 2021 \\ Accepted 22 Feb 2021 \\ Available online 28 Feb 2021 \\ Keywords: \\ Dehaasia cuneate \\ lupeol \\ antibacterial activity \\ plausible pathway \\ * Corresponding authors: \\ andirifki914@gmail.com
}

\section{Introduction}

Dehaasia cuneata belongs to Lauraceae family (Burkill, 1935). This plant is also known as 'gajus hutan' or 'pekan' in Malaysia (Hsuen,1969).

The chemical constituents of Lauraceae include neolignans, alkaloids, lignans, sesquiterpenes, flavonoids, butanolides, benzopyrans, saponin, arylpropene, alkylphenols, coumarins, ester, and steroids (Salleh and Ahmad, 2017). Previous studies reported some species of the Lauraceae exhibiting useful biological activities, such as antisplasmodic, antipyretic, antitumor, anticonvulsant, antibacterial, fungicidal, cytotoxic, cruzain inhibitory and antiviral (Zahari et al, 2014; Oliveira et al, 2015).

In our recent study, we have successfully isolated a triterpenoid from the bark of D. cuneate and performed an antibacterial test against four Gram-negative and four Gram-positive bacteria. A plausible biogenetic pathway for the formation of isolated compound leading to Ruzicka's biogenetic terpene rule is also described in this study.

\section{Materials and methods}

\subsection{General procedures}

Determination of lupeol (1) structure were done using several spectroscopic methods. Ultraviolet (UV) spectrum recorded in absolute methanol using Shidmadzu UV-160 (FST, UKM). Infrared (IR) experiment was conducted at CRIM, UKM using ATR method on FTIR Perkin-Elmer Spectrum 400. ${ }^{1} \mathrm{H}$ and ${ }^{13} \mathrm{C}$ NMR were reordered using Bruker NMR $700 \mathrm{MHz}$ cryo-probe (CRIM, UKM) at 700 and $175 \mathrm{MHz}$ respectively. Mass spectrometry data (ESIMS) was obtained using Bruker (Micro ToF-Q). Melting points was measured using XSP-12 model 500X and was uncorrected. were performed using silica gels (Merck 7734, Merck 9385, and Merck 7749, Germany) were utilized in Column and gel permeation chromatography. Thin-layer chromatography, aluminium sheets 20 $\times 20 \mathrm{~cm}$ of the silica gel $60 \mathrm{~F} 254$ of $0.25 \mathrm{~mm}$ thickness (art. no. 5554, Merck, Germany) with detection accomplished by visualizing with a UV lamp at 254 and $366 \mathrm{~nm}$. 


\subsection{Plant material}

Dehaasia cuneata bark was collected from Fraser's Hill (elevation $1000 \mathrm{~m}$ from sea level) in Peninsular Malaysia. The voucher specimen (UKMB 40311) was deposited at the Herbarium of Universiti Kebangsaan Malaysia, Bangi (UKM).

\subsection{Extraction and isolation}

The bark was cleaned with water and cut into small pieces. The sample was then air-dried to give $1.1 \mathrm{~kg}$ of dry sample which was then turn into powder powder using grinder. Methanol (MeOH) was used for extraction. After filtration, the extract was dried in vacuo at $45{ }^{\circ} \mathrm{C}$ to give crude extract. Fractionation of the extract was carried out with vacuum liquid chromatography (VLC) using a column $(80 \mathrm{~mm}$ id $\times 500 \mathrm{~mm})$ of silica gel (7734), to which 80 grams of the crude extract was subjected. The mobile phase used was n-hexane/ethyl acetate (EtOAc) with increasing polarity. Radial chromatography (RC) was utilized for purification process, using 95:5 n-hexane-EtOAc in 5\% polarity increment to yield compounds 1 (25 mg) (Rosandy et al. 2013; 2018).

\subsection{Bioassay}

The pure compound was assayed for antibacterial activity using disc diffusion methods in which the concentration of lupeol (1) was $30 \mu \mathrm{g} /$ disc (Sabri et al. 2017).

\section{Results and discussion}

\subsection{NMR data of isolated compounds}

Lupeol (1) was isolated as white crystal from fraction 3 with melting point of $215-216^{\circ} \mathrm{C}$, lit. $215-216^{\circ} \mathrm{C}$ (Reynolds et al., 1986). The mass spectrum of this compound showed molecular ion peak at $\mathrm{m} / \mathrm{z} 426$ and the molecular formula for this compound is $\mathrm{C}_{30} \mathrm{H}_{50} \mathrm{O}$. The FTIR spectrum shows a broad absorbance peak at vmax of 3367 $\mathrm{cm}^{-1}$ indicating the stretching vibration of $\mathrm{O}-\mathrm{H}$ bond. The $\mathrm{C}_{\mathrm{sp} 3}-\mathrm{H}$ stretching bands appear at 2943 and $2870 \mathrm{~cm}^{-1}$. The $1 \mathrm{H} \mathrm{NMR}$ spectrum of this compound indicated that the compound is a triterpene in nature, due to its characteristic of methyl and methylene ${ }^{1} \mathrm{H}$ chemical shifts. The ${ }^{13} \mathrm{C}-\mathrm{NMR}$ spectrum showed that 30 carbon signals, while from the DEPT-135 experiment, it was revealed that the compound comprised seven methyls, eleven methylenes, six methines. A methine carbon signal at $\delta_{\mathrm{H}} 3.21(1 \mathrm{H}$, $d d, J=4.5,11.5 \mathrm{~Hz}, \delta \mathrm{C} 79.0 \mathrm{ppm}$ ) and one quaternary carbon signal at $\delta C 151.0 \mathrm{ppm}$ suggested the presence of one hydroxyl group and an unsaturated carbon system, respectively. The HMBC spectrum revealed the correlation between $\mathrm{H}-23$ and $\mathrm{H}-24$ to $\mathrm{C}-4$
(38.8) and C-3 (79.0), and the correlation between the (H-30) and C-20 (151.0), C-29 (109.3), and C-19 (47.9). H-H COSY experiment indicated that the carbons and the protons are in the correct positions (Fig. 1). The ${ }^{3} \mathrm{~J}$ coupling appears between $\mathrm{H}-2$ and $\mathrm{H}-3$ in the COSY spectrum, as well as between the H-5 and H-6, confirming the position of the protons in the molecule. These results were in accordance to literature (Reynolds et al., 1986). Lupeol was isolated from many plants in the Lauraceae such as Neolitsea sericea (Cao et al., 2015), Beilschmiedia glabra (Lenta et al., 2015) and $B$. erythrophloia (Salleh and Ahmad, 2017). In addition, it was isolated from other families such as Ficus pseudopalma Blanco (Santiago and Mayor, 2014) and Scapium macropodum (Al Muqarrabun et al., 2014). It was first isolated in 1989 from Lupinus luteus (Barcelóñ and Muñoz, 1889).

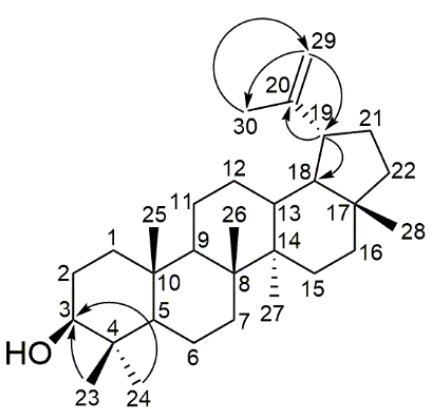

a.

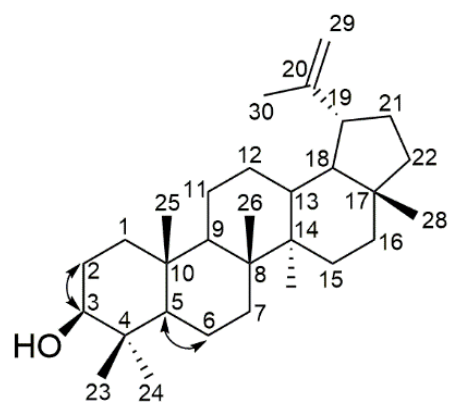

b.
Fig. 1. Correlations of lupeol (1), (a) HMBC and (b) COSY

\subsection{Antibacterial activity}

Lupeol was tested for antibacterial activity. Using disc methods, lupeol showed low inhibition which is $7.0 \pm 0.00 \mathrm{~mm}$ against $E$. coli ATCC 25922, $V$. fluvialis ATCC, B. subtilis and MRSA whereas this compound exhibited moderate inhibition (4+) against $S$. marcescens. Based on the results, it was observed that lupeol has inhibition against one Gram-negative and two Gram-positive bacteria. This is probably due to the morphological differences between Gram-negative and positive bacteria in terms of their cell wall composition. The Gram-positive bacteria only have an outer peptidoglycan which is a poor permeability barrier compared to Gram-negative bacteria that have both outer membrane and peptidoglycan. This makes the Gram-negative bacteria cell wall impermeable to most of the drugs (Sabri et al., 2017). The inhibitory zone values for all compounds are shown in Table 1.

Table 1. Antibacterial activity of the Lupeol (1) (30 $\mu \mathrm{g} /$ disc) in disc diffusion method

\begin{tabular}{|c|c|c|}
\hline Bacteria & $\begin{array}{l}\text { Inhibitory zone (mm) of } \\
\text { lupeol (1) }\end{array}$ & $\mathrm{K}^{*}$ and $\mathrm{V}^{* *}$ \\
\hline Escherichia coli ATCC 25922 * & $7.0 \pm 0.0$ & $20 \pm 1.00(\mathrm{~K})$ \\
\hline Serratia marcescens ATCC 14756* & $10.0 \pm 0.0$ & $23 \pm 1.52(\mathrm{~K})$ \\
\hline Vibrio fluvialis ATCC 33809* & $7.0 \pm 0.0$ & $35 \pm 1.04(\mathrm{~K})$ \\
\hline Vibrio cholera ATCC $39315^{*}$ & - & $10 \pm 0.00(\mathrm{~K})$ \\
\hline Bacillus subtilis ATCC $6633 * *$ & $7.0 \pm 0.0$ & $28 \pm 0.00(\mathrm{~V})$ \\
\hline Staphylococcus aureus ATCC $25923 * *$ & - & $25 \pm 0.00(\mathrm{~V})$ \\
\hline Methicillin-resistant Staphylococcus aureus (MRSA) ATCC $43300 * *$ & $7.0 \pm 0.0$ & $20 \pm 0.00(\mathrm{~V})$ \\
\hline Bacillus thruriengiensis ATCC $10792^{* *}$ & - & $22 \pm 0.00(\mathrm{~V})$ \\
\hline DMSO & $6.0 \pm 0.0$ & - \\
\hline
\end{tabular}

${ }^{*}$ Gram negative, ${ }^{* *}$ Gram positive, Diameter of disc $=6 \mathrm{~mm}$, DMSO
$\mathrm{V}^{* *}$ (Vancomycin) $30 \mu \mathrm{g}$ /disc (positive control of Gram-positive) 


\subsection{Plausible biogenetic pathway}

A triterpene, lupeol (1) is built from a simple molecule of isopentenylpyrophosphate (IPP) reacting with its allyl isomer, dimethylallylpyrophosphate (DMAPP), to form geranylpyrophosphate (GPP) catalysed by prenyltranferase. The GPP then reacts with another IPP to give farnesyl pyrophosphate (FPP). The reaction was catalyzed by farnesylpyrophosphate synthase (FPS). The squalene synthase mediates the tail-to-tail dimerization of two molecules of FPP to form squalene, which is then oxidized into 2,3-oxidosqualene by squalene epoxidase (SQE). Intramolecule cyclization occurs within the molecule, driven by enzyme oxidosqualene cyclase (OSC) forming dammarenyl cation, which then undergoes rearrangement reaction to form bacharenyl cation. A further electrophilic addition of bacharenyl cation results in lupanyl cation, which is converted to lupeol (1) by deprotonation of the methyl group (C29) by lupeol synthase (LUS) (Gallo and Sarachine, 2009; Phillips et al., 2006). A plausible biogenetic pathway from lupeol is shown in Fig. 2.

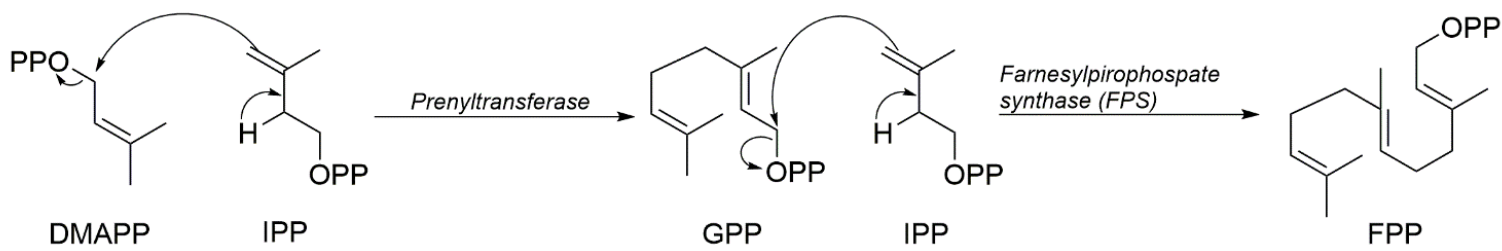

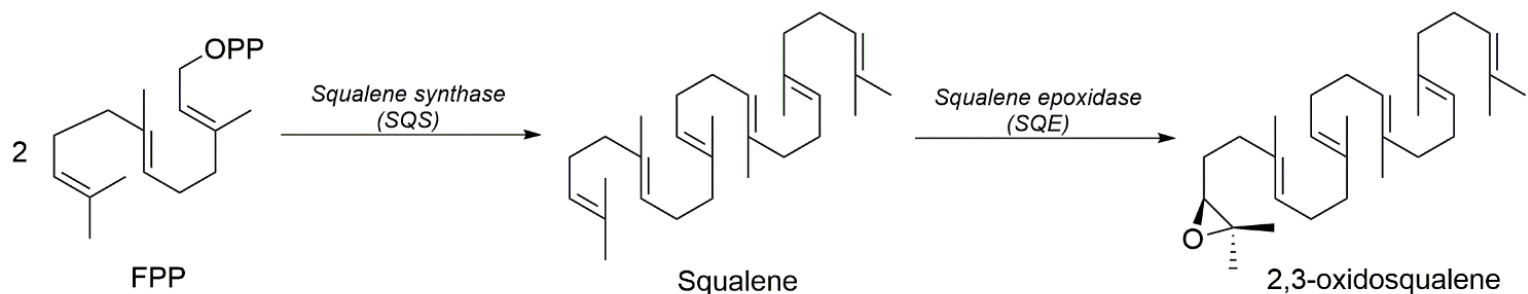

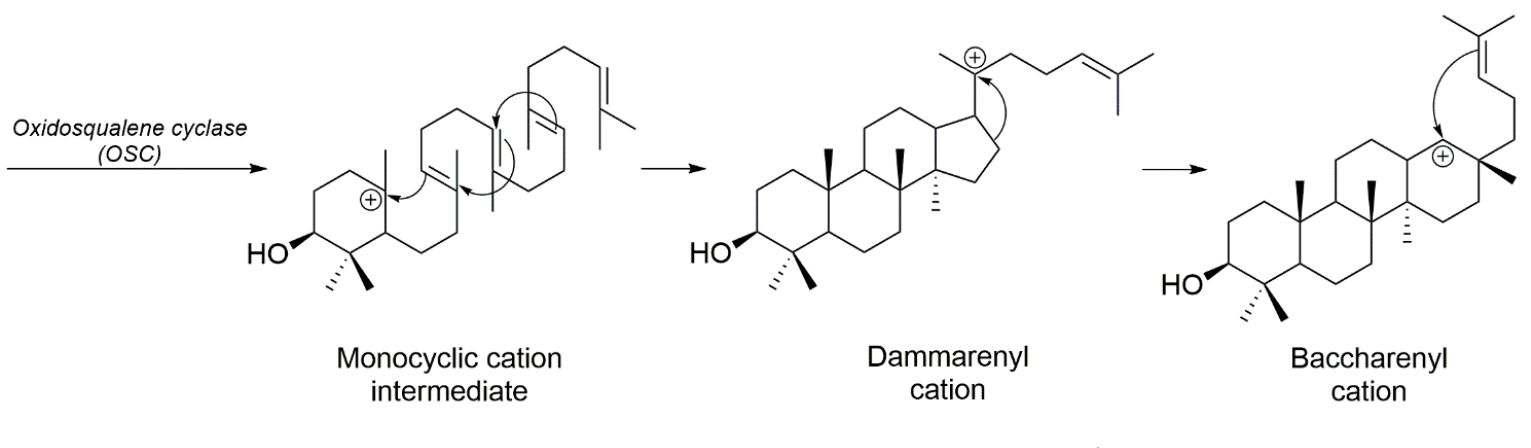

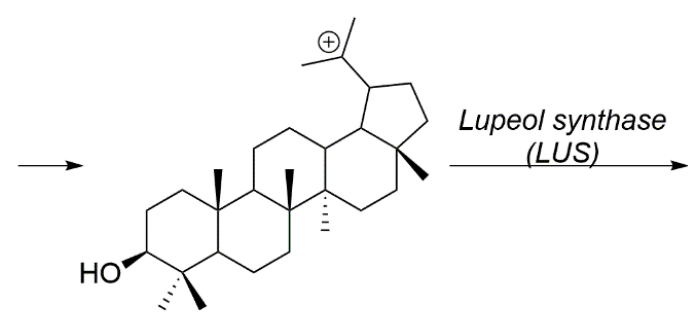

Lupanyl cation<smiles>C=C(C)[C@@H]1CCC2(C)CC[C@]3(C)C(CCC4C3(C)CCC3C(C)(C)[C@H](O)CC[C@@]34C)C12</smiles>

Lupeol (1)

Fig. 2. A plausible biogenetic pathway of lupeol

\section{Conclusion}

The phytochemical investigation of the bark of Dehaasia cuneata resulted a known triterpenoid named lupeol. The results of the antibacterial activity test showed that lupeol had a low inhibition zone value of $7.0 \pm 0.00 \mathrm{~mm}$ against Escherichia coli, Vibrio fluvialis, Bacillus subtilis, and methicillin-resistant Staphylococcus aureus (MRSA). To the best our knowledge, this compound was reported for the first time from this plant.

\section{Acknowledgement}

The Authors would like to thank to the MOHE (Malaysia) and Universiti Kebangsaan Malaysia (UKM) for the financial support under the DLP-2013-018 grant and "Program Pelajar Cemerlang (PPC)" scholarship under Public Service Department, Malaysia. Special thanks to School of Chemical Sciences, FST, UKM, and Centre for Research and Innovation Management (CRIM) UKM for technical support on NMR, LC-MSToF, UV, and FTIR instrumentation. 


\section{Conflict of interest}

No potential conflict of interest was reported by the author.

\section{NMR Data}

Lupeol (1)

Form: White crystal

MP: $215-216^{\circ} \mathrm{C}$.

IR $v$ max (cm-1): 3367 (O-H bond), 1040 (C-O bending), 761 (out-of-plane bending vibration of O-H), 2943 and 2870 (Csp3-H). 1457 (bending vibrations of Csp3-H, asymmetrical) and 1382 (symmetrical), 720 (methylene rocking bending), 1641 (olefinic, symmetrical C=C), 3072 (vibration of Csp2-H) and 882 (stretching of of Csp2-H).

UV $\lambda \max (\mathrm{MeOH}) \mathrm{nm}(\log \varepsilon): 203.53 \mathrm{~nm}$.

\section{ESIMS $[\mathrm{M}+\mathrm{Na}]^{+} \mathrm{m} / \mathrm{z} 449.2842$}

${ }^{1} \mathrm{H}$ NMR (Chloroform-d, $\left.500 \mathrm{MHz}\right) \delta \mathrm{H}: 1.70$ (3H, s, H-30), 4.59 (1H, s, H-29a) and 4.71 (1H, s, H-29b), 0.81 (3H, s, H-28), 0.96 (3H, s, H-27), 1.05 (3H, s, H-26), 0.85 (3H, s, H-25), 0.78 (3H, s, H-24), 0.99 (3H, s, H-23), $1.41(1 \mathrm{H}, \mathrm{m}, \mathrm{H}-22), 1.33(1 \mathrm{H}$, $\mathrm{m}, \mathrm{H}-21 \mathrm{a})$ and $1.94(1 \mathrm{H}, \mathrm{m}, \mathrm{H}-21 \mathrm{~b}), 1.36(1 \mathrm{H}, \mathrm{m}, \mathrm{H}-18), 1.38$ $(1 \mathrm{H}, \mathrm{m}, \mathrm{H}-16 \mathrm{a})$ and $1.49(1 \mathrm{H}, \mathrm{m}, \mathrm{H}-16 \mathrm{~b}), 1.68(1 \mathrm{H}, \mathrm{m}, \mathrm{H}-15)$, 1.68 (1H, m, H-13), 1.68 (1H, m, H-12), 1.40 (2H, m, H-11), 1.26 $(1 \mathrm{H}, \mathrm{m}, \mathrm{H}-9), 1.38(2 \mathrm{H}, \mathrm{m}, \mathrm{H}-7), 1.39(1 \mathrm{H}, \mathrm{m}, \mathrm{H}-6 \mathrm{a})$ and 1.54 (1H, m, H-6b), 0.69 (1H, d, H-5), $3.21(1 \mathrm{H}, \mathrm{dd}, \mathrm{J}=4.5,11.5 \mathrm{~Hz}$, $\mathrm{H}-3), 1.54(1 \mathrm{H}, \mathrm{m}, \mathrm{H}-2), 0.90(1 \mathrm{H}, \mathrm{m}, \mathrm{H}-1 \mathrm{a})$ and $1.68(1 \mathrm{H}, \mathrm{m}, \mathrm{H}-$ 1b)

${ }^{13} \mathrm{C}$ NMR (Chloroform-d, $\left.125 \mathrm{MHz}\right) \delta \mathrm{H}: 19.3$ (C-30), 109.3 (C-29), 18.0 (C-28), 14.5 (C-27), 15.9 (C-26), 16.1 (C-25), 15.4 (C-24), 27.9 (C-23), 39.9 (C-22), 29.8 (C-21), 151.0 (C-20), 47.9 (C-19), 48.2 (C-18), 43.0 (C-17), 35.5 (C-16), 27.4 (C-15), 42.8 (C-14), 38.0 (C-13), 25.1 (C-12), 20.9 (C-11), 37.1 (C-10), 50.4 (C-9), 40.8 (C-8), 34.2 (C-7), 18.3 (C-6), 55.2 (C-5), 38.8 (C-4), 79.0 (C-3), 27.4 (C-2), 38.6 (C-1)

\section{References}

Al Muqarrabun LMR, Ahmat N, Aris SRS, Shamsulrijal N, Baharum SN, Ahmad R, Rosandy AR, Suratman MN, Takayama H. 2014. A new sesquiterpenoid from Scaphium macropodum (Miq.) Beumee. Nat Prod Res 28(9): 597-605. doi: 10.1080/14786419.2014.886211

Barcelóñ AR, Muñoz R. 1989. Epigenetic control of a cell wall scopoletin peroxidase by lupisoflavone in Lupinus. Phytochemistry 28(5), 1331-3. doi: 10.1016/S0031-9422(00)97740-9
Blume CL. 1837. Rumphia 1. Sulpke, Leiden, Amsterdam, etc.

Burkill IH. 1935. A dictionary of the economic products of the Malay peninsula (1st Ed.). London: Crown Agents for the Colonies.

Cao Y, Gao X-L, Su G-Z, Yu X-L, Tu P-F, Cha X-Y. 2015. The genus Neolitsea of Lauraceae: a phytochemical and biological progress. Chem Biodivers 12(10): 1443-65. doi: 10.1002/cbdv.201400084

Gallo MB, Sarachine MJ. 2009. Biological activities of lupeol. Int $J$ Biomed Pharm Sci-Global Science Books 3(1): 46-66.

Hsuen K. 1969. Orders and families of Malayan seed plants. Kuala Lumpur, Malaysia: University of Malaya.

Lenta BN, Chouna JR, Nkeng-Efouet PA, Sewald N. 2015. Endiandric acid derivatives and other constituents of plants from the genera Beilschmiedia and Endiandra (Lauraceae). Biomolecules 5(2): 910 42. doi: 10.3390/biom5020910

Oliveira Filho AA, Fernandes HMB, Assis TJCF. 2015. Lauraceae's family: a brief review of cardiovascular effects. IJPPR 7(1): 22-6.

Phillips DR, Rasbery JM, Bartel B, Matsuda SP. 2006. Biosynthetic diversity in plant triterpene cyclization. Curr Opin Plant Biol 9(3): 305-14. doi: 10.1016/j.pbi.2006.03.004

Reynolds WF, McLean S, Poplawaki J, Enriquez RG, Escobar LI, Leon I. 1986. Total assignment of $13 \mathrm{C}$ and $1 \mathrm{H}$ spectra of three isomeric triterpenol derivatives by 2D NMR: an investigation of the potential utility of ${ }^{1} \mathrm{H}$ chemical shifts in structural investigation of complex natural products. Tetrahedron 42(13): 3419-28. doi: 10.1016/S00404020(01)87309-9

Rosandy AR, Din LB, Yaacob WA, Yusoff NI, Sahidin I, Latip J, Baharum $\mathrm{SN}$, Noor NM. 2013. Isolation and characterization of compounds from the stem bark of Uvaria rufa (Annonaceae). Malaysian Journal of Analytical Sciences 17(1): 50-8.

Rosandy AR, Ying YC, Kqueen CY, Lim SJ, Latip J, Murad AMA, Bakar MA, Khalid RM. 2018. (-)-Glaciantarcin, a new dipeptide and some secondary metabolites from the psychrophilic yeast Glaciozyma antarctica PI12. Sains Malaysiana 47(11): 2693-8. doi: 10.17576/jsm2018-4711-12

Sabri NA, Ahmad WYW, Abdullah NS, Ibrahim N. 2017. The chemical constituents from the fruits of Johannesteijsmannia altifrons and antibacterial activity. Malaysian Journal of Analytical Sciences 21(2): 304-11. doi: 10.17576/mjas-2017-2102-05

Salleh WMNHW, Ahmad F. 2017. Phytochemistry and biological activities of the genus Ocotea (Lauraceae): a review on recent research results (2000-2016). JAPS 7(5): 204-18. doi: 10.7324/JAPS.2017.70534

Santiago LA, Mayor ABR. 2014. Lupeol: an antioxidant triterpene in Ficus pseudopalma Blanco (Moraceae). Asian Pac J Trop Biomed. 4(2): 109-18. doi: 10.1016/S2221-1691(14)60218-5

Zahari A, Cheah FK, Mohamad J, Sulaiman SN, Litaudon M, Leong KH, and Awang K. 2014. Antiplasmodial and antioxidant isoquinoline alkaloids from Dehaasia longipedicellata. Planta Med 80(7): 599603. doi: $10.1055 / \mathrm{s}-0034-1368349$ 